\title{
A comparative study on growth performance and survival rate of Clarias gariepinus burchell, 1822 and Heterobranchus longifilis valenciesnnes, 1840 under water recirculation system
}

\author{
Adams Femi Yakubu ${ }^{1}$, Nkemakolam Akajiaku Nwogu ${ }^{1,}$, Ebenezer Dayo Olaji ${ }^{1}$, \\ Olufemi Oluseun Ajiboye ${ }^{1}$, James Ocheme Apochi ${ }^{2}$, Temitope Esther Adams ${ }^{1}$, \\ Esther Eriromurun Obule ${ }^{1}$, Mercy Eke ${ }^{1}$ \\ ${ }^{1}$ Aquaculture Department, Nigerian Institute for Oceanography and Marine Research, P.M.B. 4015, Sapele, Delta State, Nigeria \\ ${ }^{2}$ Agriculture Research Council of Nigeria (ARCN), Abuja, Nigeria
}

Email address:

nwogunkem@yahoo.com (N. A. Nwogu)

To cite this article:

Adams Femi Yakubu, Nkemakolam Akajiaku Nwogu, Ebenezer Dayo Olaji, Olufemi Oluseun Ajiboye, James Ocheme Apochi, Temitope Esther Adams, Esther Eriromurun Obule, Mercy Eke. A Comparative Study on Growth Performance and Survival Rate of Clarias Gariepinus Burchell, 1822 and Heterobranchus longifilis Valenciesnnes, 1840 under Water Recirculation System. Agriculture, Forestry and Fisheries. Vol. 3, No. 1, 2014, pp. 30-33. doi: 10.11648/j.aff.20140301.16

\begin{abstract}
The growth performance and survival rate of Clarias gariepinus burchell, 1822 and Heterobranchus longifilis valenciesnnes, 1840 under water recirculation system were examined. The post fingerlings of the two species were stocked at $486 \mathrm{fish} / \mathrm{m}^{3} /$ tank and fed coppens ${ }^{\circledR}$ feed for sixteen weeks. Fish body weights were determined bi-weekly using electronic weighing balance. Final mean weight of $170.49^{\mathrm{a}} \pm 14.39 \mathrm{~g}$ (C. gariepinus) and $42.78^{\mathrm{b}} \pm 1.57 \mathrm{~g}$ (H. longifilis) were obtained. H. longifilis had a better survival rate (86.21\%) compared to C. gariepinus (66.94\%). The performance index (PI) showed that $C$. gariepinus $\left(\mathrm{PI}=101.90^{\mathrm{b}}\right)$ performed better than $H$. longifilis $\left(\mathrm{PI}=30.50^{\mathrm{a}}\right)$. The water quality variables were similar in the culture tanks. The results of the present experiment showed that post fingerlings of the two species of clariid catfish have different growth performance, survival and feed utilization efficiency under water recirculation system with C. gariepinus having better growth performance and yield than $\mathrm{H}$. longifilis.Therefore, the culture of Clarias gariepinus clariid catfish under water recirculation system is recommended for better yield and profitability.
\end{abstract}

Keywords: Growth Performance, Catfish, Intensive Culture, Survival Rate, Fingerlings

\section{Introduction}

Three systems are used in culturing fish namely: extensive, semi-intensive and intensive systems. Extensive system requires low capital input and is greatly influenced by environmental conditions. Earthen ponds or natural water bodies are used and low stocking densities are employed. Little or no feeding is practiced. In semi intensive system, feeding is practiced, the natural productivity of the pond harnessed, and supplemental aeration is normally done. Production level can be as high as 5 tonnes. Intensive systems usually employ circular tanks, raceways and cross ways. Intensive systems generally require high capital inputs, continuous aeration and the feed used is nutritionally complete. Cost of production is high and precise management is a pre-requisite for success [1]. Intensive culture of finfish in Water Recirculation System (WRS) is a production technique that reuses fish culture water and has been adopted for African catfish (Clarias gariepinus) in Europe and America [2]. Nigeria has a high potential to develop its fish farming to increase the amount of fish that is produced in the country because of its high demand and favourable scale price.

The most cultured fish species in Africa especially in Nigeria are Clarias gariepinus [3], Heterobranchus species [4] and their hybrids. Under different culture systems, the above species exhibit different feed utilization efficiencies, growth performance, and disease resistance [5].

Previous investigation on growth response and survival rate of Clariid catfish, particularly Clarias gariepinus and Heterobranchus longifilis showed that both species exhibit 
fast growth and ability to withstand adverse condition in earthen ponds and concrete tanks [6].

Heterobranchus species has some advantages over Clarias species such as higher growth rate, feed conversion [7] and remarkable yield [8] while Clarias species mature earlier and has higher fecundity $[6,10,11,12]$. However, there is paucity of information on the culture of Heterobranchus longifilis under Water Recirculation System. Therefore, this study aimed at comparing the growth performance and survival rate of Clarias gariepinus and Heterobranchus longifilis under Water Recirculation System.

\section{Materials and Methods}

\subsection{Study Area}

The experiment was conducted in the Water Recirculation System of Nigerian Institute for Oceanography and Marine Research, Sapele Station, Nigeria.

\subsection{Collection and Stocking of Experimental Fish}

Post fingerlings of Clarias gariepinus and Heterobranchus longifilis were obtained from a reputable hatchery (Heritage Fish Farm, Sapele, Nigeria) and transported in plastic containers. On arrival at the experimental site, the water in the containers were replaced with fresh water and the post fingerlings were allowed to remain in the containers for three hours to allow them recover from transportation stress before been released into WRS culture tanks. The post fingerlings were stocked at $486 \mathrm{fish} / \mathrm{m}^{3} / \mathrm{tank}$.

\subsection{Feeding and Measurement}

Each culture treatment was fed with Coppens ${ }^{\circledR}$ (Floating diet) a completely dry catfish feed containing $45 \%$ crude protein, $12 \%$ fat, $2.2 \%$ calcium, $1.2 \%$ potassium, $0.5 \%$ Ash, $2.2 \%$ fiber, $60 \mathrm{ppm}$ minerals and vitamins A (10000 IU/kg), $\mathrm{E}(200 \mathrm{mg} / \mathrm{kg})$ and $\mathrm{C}(100 \mathrm{mg} / \mathrm{kg})$. The post fingerlings were fed $5 \%$ of their body weight twice daily, morning ( 6 am -8 am) and evening $(4.00 \mathrm{pm}-6.00 \mathrm{pm})(\mathrm{GMT}+1)$ for 16 weeks. Fish body weight were determined and recorded to the nearest $0.01 \mathrm{~g}$, using electronic weighing balance (Metller PC 180). Measurement exercises were completed on each sampling day before feeding with appropriate ration.

\subsection{Physiochemical Parameter}

Water quality parameters, such as dissolved oxygen, $\mathrm{pH}$, surface, and atmospheric water temperatures were monitored daily according to the method of [5].

\subsection{Nutrient Utilization Parameters}

Nutrient utilization parameters were determined based on the following formulae:
Percentage Weight Gain $(\%)=\frac{100(Y-X)}{X}[13]$

Where $\mathrm{Y}=$ Final Mean Body Weight $(\mathrm{g})$

$\mathrm{X}=$ Initial Mean Body Weight (g)

Specific Growth Rate (SGR\%day) was calculated [14] and converted into percentage thus:

$\mathrm{SGR}=\frac{100 \times[\operatorname{In}(\text { Final body weight })-\operatorname{In}(\text { Initial body weight })]}{\text { Rearing period in days }}$

Where "in" represents natural logarithm.

Food Conversion Efficiency (FCE)

$\mathrm{FCE}=\frac{\text { Final Weight by Fish X } 100}{\text { Weight of feed given }} \quad[16]$

Survival Rate (SR) was calculated according to [14]

SR $(\%)=\frac{\text { Total fish number harvested }}{\text { Total fish number stocked }} \times 100$

$\mathrm{PI}=\frac{\text { Survival Rate X Final Mean Weight }(\mathrm{g}) \text {-Initial Mean body weight }(\mathrm{g})}{\text { Rearing duration in days }}[3]$

\subsection{Statistical Analysis}

Data was subjected to one-way analysis of variance (ANOVA) using SPSS software. Differences between means were analysed using Duncan's Multiple Range Test (DMRT)

\section{Results and Discussions}

The result on growth performance and bi-weekly weight gain of Clariid catfish Clarias gariepinus and Heterobranchus longifilis cultured under water recirculation system for 16 weeks is presented in Table 1 and Figure 1 respectively. Clarias gariepinus has the highest mean weight gain of $173.78^{\mathrm{b}} \pm 14.30 \mathrm{~g}$ while the lower value of $42.78^{\mathrm{a}} \pm 1.57 \mathrm{~g}$ was recorded for Heterobranchus longifilis. There was a significant difference $(\mathrm{P}<0.05)$ in weight gain between the two species.

The highest percentage weight gain and mean specific growth rate (SRG) value of $5182.07 \%$ and $3.54^{\mathrm{a}}$ respectively was obtained for Clarias gariepinus. While $1278.06 \%$ and $2.24^{\mathrm{b}}$ for percentage weight gain and specific growth rate respectively were recorded for Heterobranchus longifilis.

Heterobranchus longifilis showed the highest survival rate value $(86.21 \%)$ against $66.94 \%$ recorded for Clarias gariepinus.

Final mean food conversion efficiency (FCE) was higher in Clarias gariepinus $\left(17.13^{\mathrm{b}}\right)$ as compared to $8.17^{\mathrm{a}}$ obtained for Heterobranchus longifilis.

The performance Index (PI) data was highest in Clarias gariepinus $\left(101.90^{\mathrm{b}}\right)$ whereas lower value of $30.50^{\mathrm{a}}$ was calculated for Heterobranchus Longifiis.

The general trend for bi-weekly growth pattern for the two species showed a stepwise pattern with C. gariepinus 
been the highest while $H$. longifilis was lower (Fig. 1).

There was no significant difference $(\mathrm{P}>0.05)$ in the water quality of the culture system (data not shown)

Observation on these growth parameters disagreed with those of previous researchers [18, 11]. Reference [7] observed a drastically slower growth rate in Clarias gariepinus than Heterobranchus Longifilis in their study on growth performance, food conversion ratio (FCR) and survival rate after 254 days grow out period. In a similar work carried out by [19], the results showed that hybrid (Heteroclarias) had the best weight gain in all the three-culture system followed by Clarias gariepinus and least with Heterobranchus longifilis, which is in agreement with the findings in this present study.

Survival rate of Heterobranchus longifilis was higher compared to Clarias gariepinus. However, [20] among others have demonstrated that survival decrease as stocking density increases. This principle may not be the reason for the significance different in the survival rate of the two clariid catfish because both species were stocked at the same stocking density. The observed differences may be because of high rate of cannibalism in Clarias gariepinus compared to Heterobranchus longiflis. It was also observed in the present study that Heterobranchus longifilis grew uniformly as compared to Clarias gariepinus. This may also account for the high rate of cannibalism observed in Clarias gariepinus hence low survival rate recorded. However, despite the low survival rate observed in $C$. gariepinus, it had a better yield than $H$. longifilis.

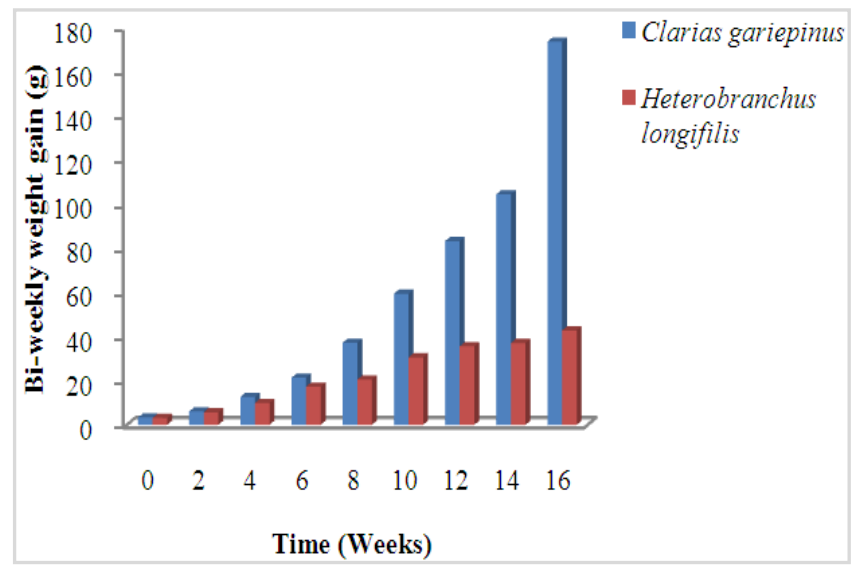

Figure 1: Bi-weekly weight gain of C. gariepinus and H. longifilis fed

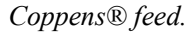

\section{Conclusion}

The result of growth performance and bi-weekly weight gain in two clariid catfishes Clarias gariepinus and Heterobranchus longifilis reveals that the post fingerlings have different growth performance and feed utilization efficiency under water recirculation system examined in this study with Clarias gariepinus performing better than Heterobranchus longifilis. Therefore, the culture of Clarias gariepinus clariid catfish under water recirculation system is recommended for better yield and profitability.

Table 1. Growth performance and survival of H. longifilis and C. gariepinus cultured under water recirculation system for sixteen weeks.

\begin{tabular}{lll}
\hline Growth Parameter & Fish Species & Clarias gariepinus \\
\hline Initial Mean Weight (g) & Heterobranchus longifilis & $3.29 \pm 0.38^{\mathrm{a}}$ \\
Final Mean Weight (g) & $3.10 \pm 0.22^{\mathrm{a}}$ & $173.78 \pm 14.30^{\mathrm{b}}$ \\
Final Mean Weight Gain (g) & $42.78 \pm 1.57^{\mathrm{a}}$ & $170.49 \pm 14.39^{\mathrm{a}}$ \\
\% Weight Gain (\%) & $39.62 \pm 1.44^{\mathrm{a}}$ & $5182.07^{\mathrm{b}}$ \\
Final Mean Specific growth Rate (SGR \% day) & $1278.06^{\mathrm{a}}$ & $3.54^{\mathrm{a}}$ \\
Survival Rate (SR \%) & $2.24^{\mathrm{a}}$ & $66.94^{\mathrm{b}}$ \\
Final Mean Food Conversion Efficiency (FCE) & $86.21^{\mathrm{a}}$ & $17.13^{\mathrm{b}}$ \\
Performance Index (PI) & $8.17^{\mathrm{a}}$ & $101.90^{\mathrm{b}}$ \\
\hline
\end{tabular}

a,b denote significantly different values in a row at $\mathrm{P}<0.05$ level by one-way ANOVA and Duncan's Multiple Range Test.

\section{Acknowledgements}

The authors are grateful to Nigerian Institute for Oceanography and Marine Research, Lagos, Nigeria for sponsoring this work.

\section{References}

[1] Watanabe, W.O., Losordo, T.M., Fitzsimmons, K. \& Hanley, F. (2002). Tilapia production systems in the Americas: technological advances, trends, and challenges. Reviews in Fish Science, 10:465 - 498 .
[2] Akinwole, A.O. \& Faturoti, E.O. (2006). Biological performance of Africa catfish (Clarias garienpinus) cultured in recirculation system in Ibadan. Aquaculture \& Cultural Engineering, 36:18-23.

[3] Engle, C.R. \& Valderrama, D. (2001).Effect of stocking density on production characteristics, coasts, and risk of producing fingerlings channel catfish. North American Journal of Aquaculture, 63: 201-207.

[4] Ellis, T., North, B., Scott, A.P., Bromage, N.R., Porter, M., \& Gadd, D.(2002). The relationships between stocking density and welfare in farmed rainbow trout. Journal of Fish Biology, 61:493-531. 
[5] Gamal,O.E., Nabil, A.I., \& Mohamed, Y.A.Z. (2008). Influence of fertilizers' types and stocking density on water quality and growth performance of Nile tilapia-African catfish in polyculture system, 8th International Symposium on Tilapia in Aquaculture, p. 157.

[6] Viveen, W.J., Richter, C.J., Van Oordt, P.G., Janssen J.A., \& Huisman, E.A. (1985).Manual for the culture of the African catfish (Clarias gariepinus).Directorate General for Int. Cooperation, The Hague, 93pp.

[7] Anibeze, C.I.P., \& Eze, A., (2000). Growth rates of two African catfishes (Osteichthys clariidae) in homestead concrete ponds. Journal Aquatic Sciences, 15:55-58.

[8] Legendre, M. (1986). Seasonal changes in sexual maturity and fecundity and HCG-induced breeding of the catfish, Heterobranchus longifilis val. (Clariidae), reared in Ebrie Lagoon (Ivory Coast). Aquaculture, 55:201-213.

[9] Anibeze, C.I.P. (1995). Aspect of the ecology of Heterobranchus longifilis(Val 1840) in Idodo River Basin (Nigeria) and their application to aquaculture. Ph.D Thesis, University of Nigeria, Nsukka, 157 pp.

[10] Egwui, P.C. (1986). Yields of the African catfish, Clarias gariepinus (Burchell) from a low input, homestead, concrete pond. Aquaculture, 55:87-91.

[11] Legendre, M., Teugels, G.G., Cauty, C., \& Jalabert, B. (1992) A comparative study on the morphology, growth rate and reproduction of Clarias gariepinus (Burchell, 1822); Heterobranchus longifilis (val 1840) and their hybrids (Pisces: Clariidae). Journal of Fish Biology, 40:57-79.

[12] Nwadukwe, F.O., \& Nawa, I.G. (2000). Effects of rearing periods on the production of hybrid catfish (Clarias gariepinusx Heterobranchus longifilis) fingerlings. Journal of Aquatic Sciences, 15:23-26.

[13] Adewolu, M.A., Ogunsanmi, A.O., \& Yunusa, A. (2008) Studies on growth performance and feed utilization of two
Clariid catfish and their hybrid reared under different culture systems, European Journal of Scientific Research, 23(2):252-260

[14] Pascal, G.V.D., Nieuwegiessen, A.J.V., Johan, J. \& Johan, W.S. (2006). The effects of stocking density on welfare indicators in African catfish Clarias gariepinus (Burchell), AQUA Meeting, p. 184.

[15] Benedict, O.O., Gabriel,U.I., \&Ezekiel, O.A. (2005). Effect of stocking size of the predatory African catfish (Heterobranchus longifilis V.) on the growth performance of Nile Tilapia (Oreochromis niloticusL.) in pond culture. International Journal of Fisheries and Aquaculture, $1(3): 38-43$.

[16] TBoujard, L., Labbé, L., \& Aupérin, B. (2002). Feeding behaviour, energy expenditure and growth of rainbow in relation to stocking density and food accessibility. Aquaculture Research, 33:1233-1242.

[17] Coulibaly, A.I.N., Ouattara, T., Koné, V., Douba, J.N., Snoeks, G.B.G., \& Kouamelan, E.P. (2007). First results of floating cage culture of the African catfish Heterobranchus longifilis Valenciennes, 1840: Effect of stocking density on survival and growth rates. Aquaculture, 263:61-67.

[18] Nlewadim, A.A., Onuoha, G.C., \& Aluko, P.O. (2004).Studies on the growth and survival of fry and fingerlings of Clariid catfish species: Clarias gariepinus (Burchell, 1822), Heterobranchus bidorsalis (Geoffry, 1809) and $H$. longifilis(Val. 1840). Journal of Aquaculture in the Tropics, 19(1):1-14.

[19] Ogunsanmi, A.O., Yunusa, A., \& Adewolu, M.A (2008) Studies on growth performance and feed utilization of twoclariid and their hybrid reared under different culture systems. European Journal of Scientific Research, 23(2).

[20] Teng, S.K., \& Chua, T.E. (1978). Effect of Estuary grouper, Epinephelus Salmonides Maxwell, Cultured in floating Net-cages. Aquaculture, 15:273-287s 